\title{
The design and preparation of fluorescent labeled chitosan nanoparticles for intestinal delivery
}

\author{
Golshan Karimi Zindashti ${ }^{1}, \underline{\text { Sepideh Khaleghi }}{ }^{2}$, Fahimeh Nemati Mansur $^{2}$, Fatemeh Rahbarizadeh $^{3}$ \\ ${ }^{I}$ MSc Student, Department of Medical Biotechnology, Faculty of Advanced Science and Technology, Tehran Medical \\ Sciences, Islamic Azad University, Tehran, Iran \\ ${ }^{2}$ Assistant Professor, Department of Medical Biotechnology, Faculty of Advanced Science and Technology, Tehran \\ Medical Sciences, Islamic Azad University, Tehran, Iran \\ ${ }^{3}$ Associate Professor, Department of Medical Biotechnology, Faculty of Medical sciences, Tarbiat Modares University, \\ Tehran, Iran
}

\begin{abstract}
Background: Chitosan is a biodegradable, biocompatible polymer regarded as safe for human dietary. Nanoparticles (NP) prepared with chitosan derivatives typically possess a positive surface charge and mucoadhesive properties such that can adhere to mucus membranes and release the drug payload in a sustained release manner. Current study is focused on preparation several kinds of chitosan formulations and different concentrations of cross linking agents in various conditions and characterization for achievement of most stable and biocompatible nanoparticle which labeled by FITC for in vitro tracking .

Analysis method: In order to better investigate, in addition to chitosan, carboxymethyl chitosan was used. Preparation of chitosan nanoparticles is done by Ionotropic gelation method using different concentration of sodium tripolyphosphate (TPP) as cross-linking agent. Moreover, the synthesis of FITC-labeled chitosan at a combination of time, $\mathrm{pH}$, different concentrations of salt and enzyme was investigated to produce stable nanoparticles for intestinal drug delivery. Physical characterization of nanoparticles were estimated by DLS and TEM as well as conjugation and covalent links were confirmed by FITR.

Results: The size of the nanoparticles by transmission electron microscopy (TEM) was about $100 \pm 50$. Hydrodynamic diameter was measured by DLS around $150 \pm^{\circ} 0 \mathrm{~nm}$. In FTIR, covalent conjugation to the chitosan nanoparticles with control samples was confirmed. UV spectroscopy was used to determine the efficiency of conjugation which was over $70 \%$.

Conclusion: All of these findings favor the notion that the FITC conjugated chitosan nanoparticles produced in our work may offer promise for the development of an efficient therapeutic and diagnosis carrier for colon cancer in the future. However, further investigation is required to provide more evidence on diff erent aspects of the targeting activity and stability of this nanoparticle in in vivo.
\end{abstract}

Keywords: Chitosan nanoparticle, FITC, Intestine, Colon cancer, Stability.

Cited as: Karimi Zindashti G, Khaleghi S, Nemati Mansur F, Rahbarizadeh F. The design and preparation of fluorescent labeled chitosan nanoparticles for intestinal delivery. Medical Science Journal of Islamic Azad University, Tehran Medical Branch 2020; 30(4): 352-362.

Correspondence to: Sepideh Khaleghi

Tel: +989102005098

E-mail: s.khaleghi@iautmu.ac.ir

ORCID ID: 0000-0002-1817-3116

Received: 29 Sep 2019; Accepted: 10 Dec 2020 
مجله علوم يزشكى دانشَاه آزاد اسلامى

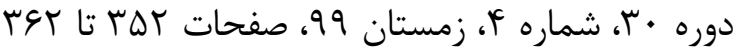

\section{طراحى و سنتز نانوذرات كيتوزان نشاندار جهت انتقال هدفمند دارو به روده}

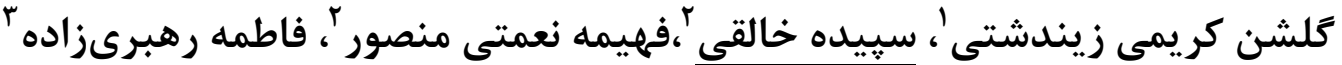

' دانشجوى كارشناسى ارشد، كروه بيوتكنولوزى، دانشكده علوم و فناورىهاى نوين، علوم يزشكى تهران ، دانشخاه آزاد اسلامى تهران، ايران

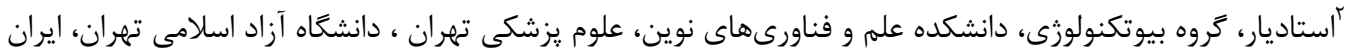

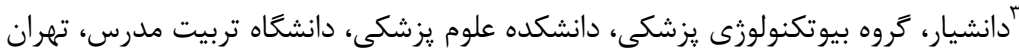

\section{جكيده}

سابقه و هدف: كيتوزان نوعى بليمر تجزيه بذير و زيست سازكار /ست كه براى رزيمر غذايى انسان بى خطر محسوب مى شود.

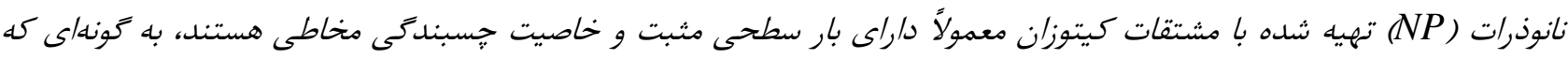

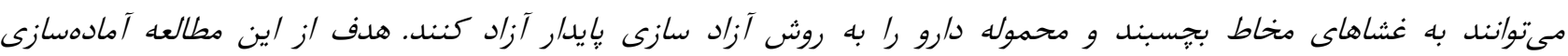

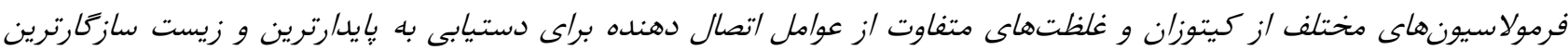

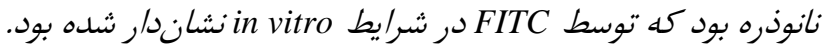

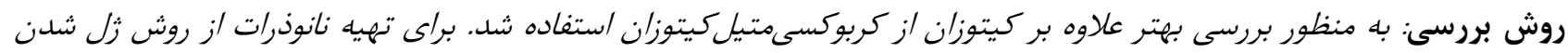

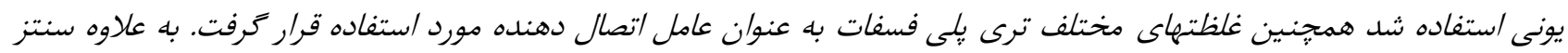

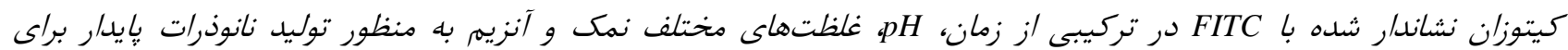

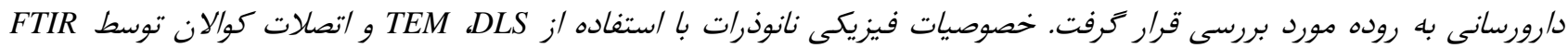

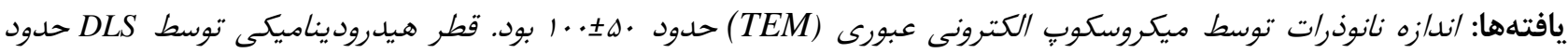

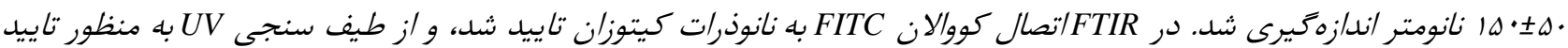

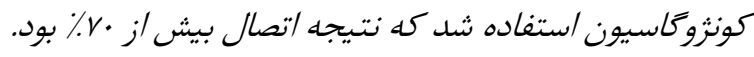

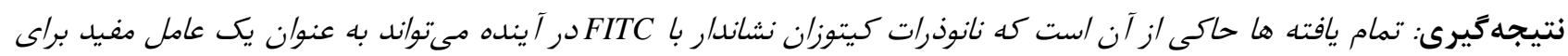

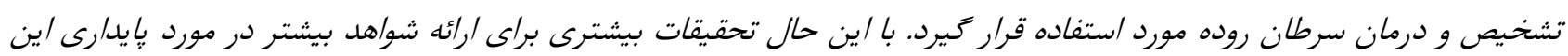
نانوذرات در شرايط in vivo لازم است. وازخكان كليدى: نانوذرات كيتوزان، FITC، روده، سرطان روده، بإيدرى.

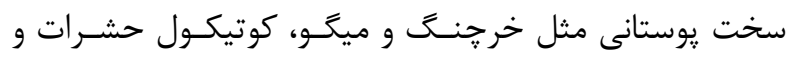
مقدمه

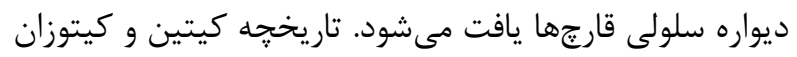

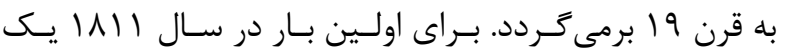

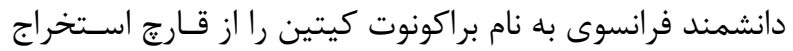

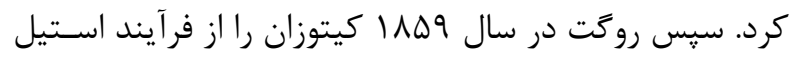

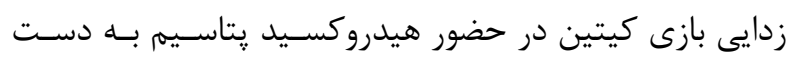

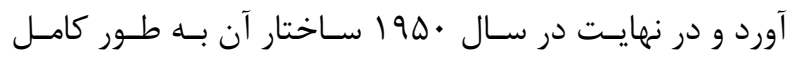

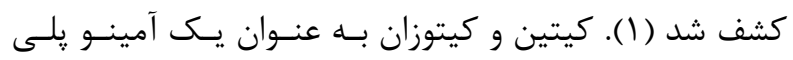
كيتين از فراوانترين بيويليمرهـا بعـد از سـلولز اسـت. كيتـين

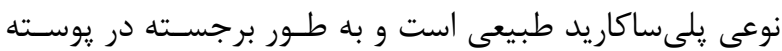

أدرس نويسنده مسئول: تهران، كروه بيوتكنولوزىى، دانشكده علـم و فنـاورىهـاى نـوين، دانشـاه علـوم يز شكى آزاد اسلامى، سيبده خالقى (email: s.khaleghi@iautmu.ac.ir) ORCID ID: 0000-0002-1817-3116 تاريخ دريافت مقاله:

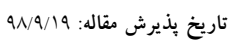


با استفاده از يك سـرى نمـكهــا اتصـالات عرضى در در داخـل

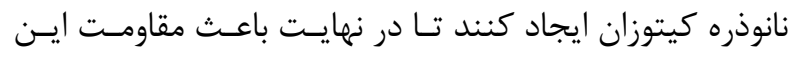

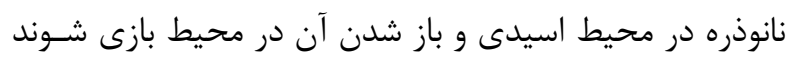

از اين رو در اين يزوهش سعى شد كـهـ از كيتـوزان بـهـ عنــوان

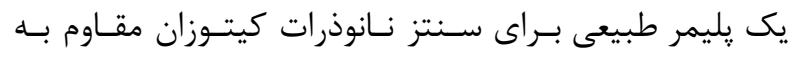

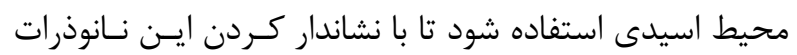

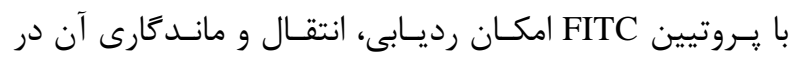

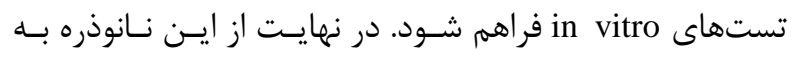

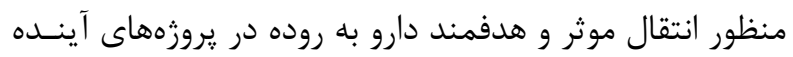

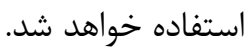

\section{مواد و روشهها - مواد}

مواد

كيتوزان با وزن مولكولى يايين و فلوئورسين ايزوتيوسـيانات FITC

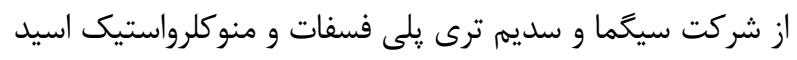

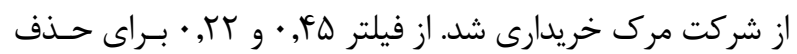

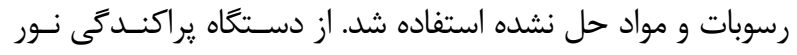

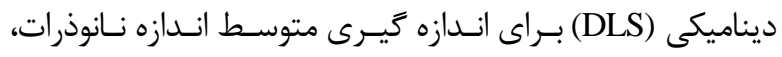

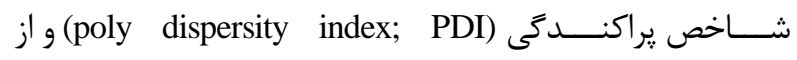
ميكروسكويى الكترونى عبورى براى بررسى مورفولـوزى نـانوذرات

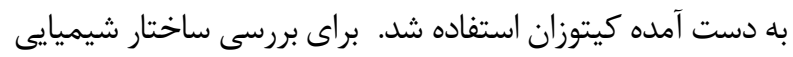

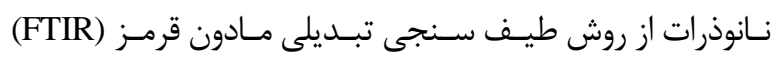

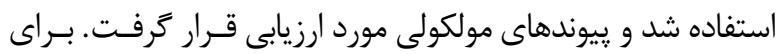
تعيين درصد جذب نانو ذرات از فلورومترى استفاده شد.

\section{توليد كربوكسى متيل كيتوزان}

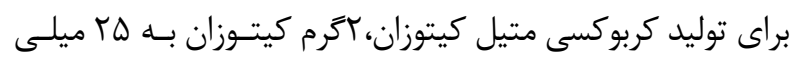

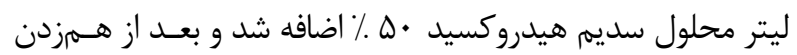

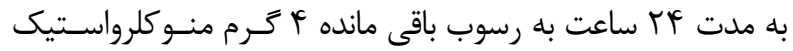

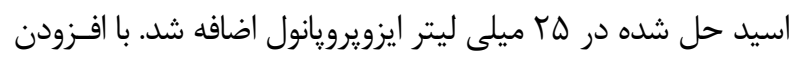
قطره قطره اتانول مطلق كيتوزان رسوب داده شد. عمليات تشكيل ين يزويل

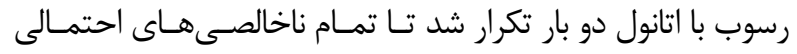

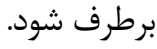

تهيد نانوذرات كيتوزان و كربوكسى متيل كيتوزان

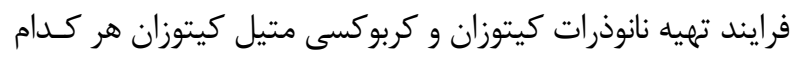

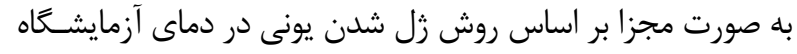

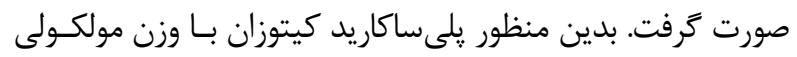

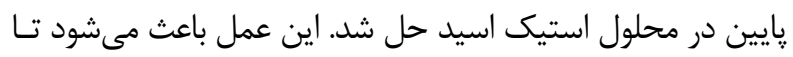

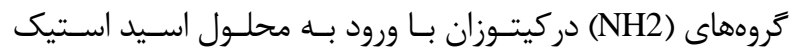

ساكاريد طبيعى كه داراى سـاختمان بـىنظيـر و خصوصـياتى

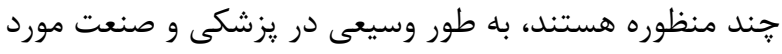

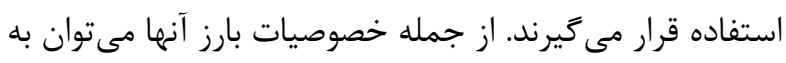

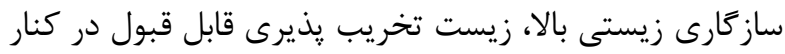

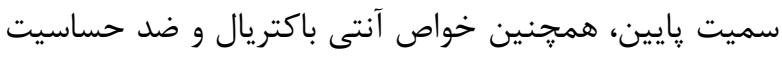

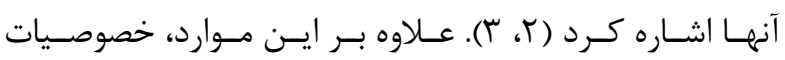

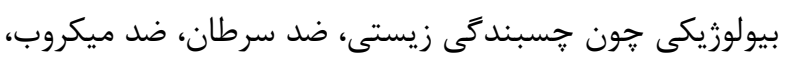

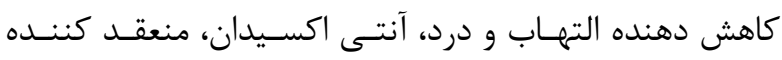

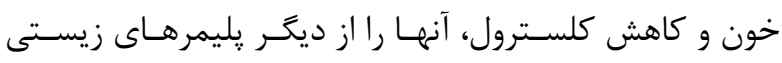

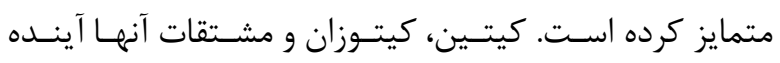
روشنى به عنوان يك عامل كمكى در انتقال و رهاسازى داروها

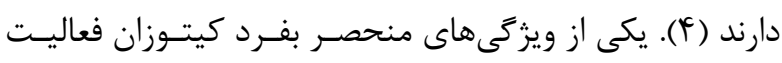

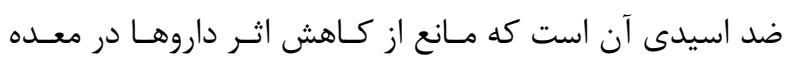

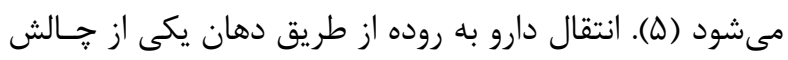

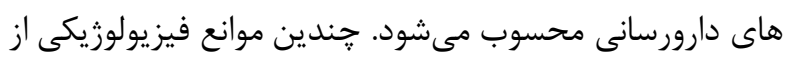

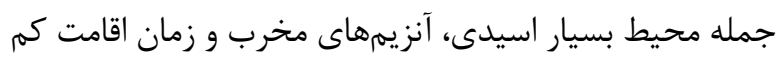

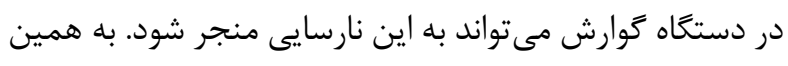

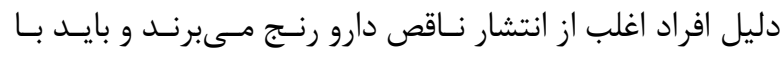

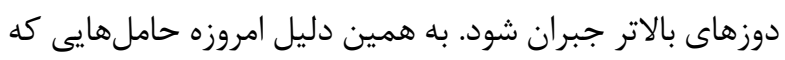

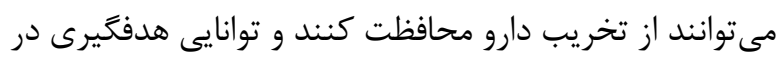

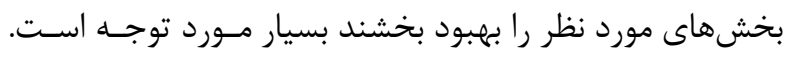

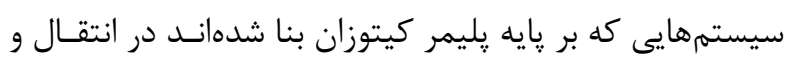

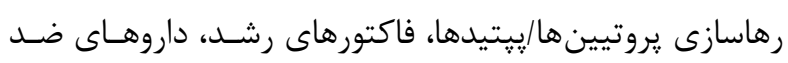

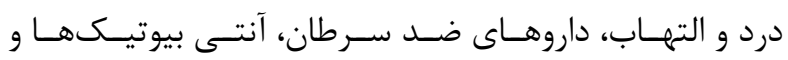

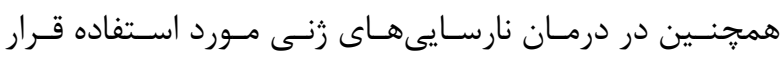

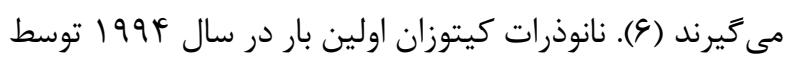

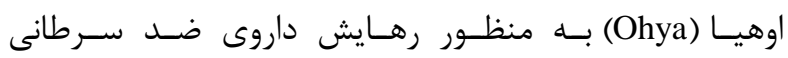

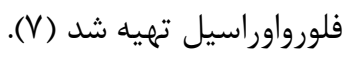

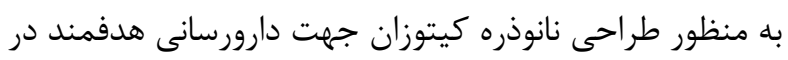

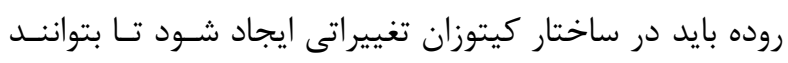

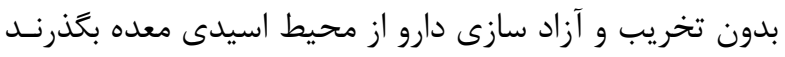

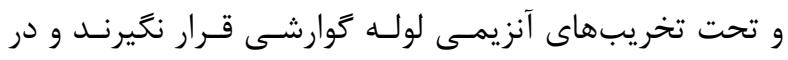

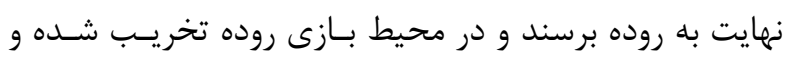

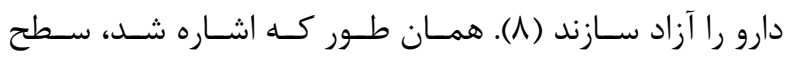

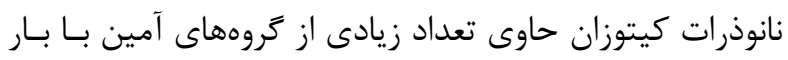

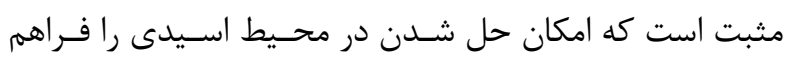

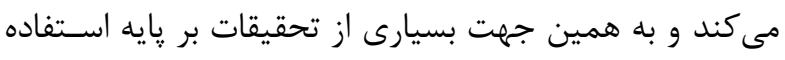

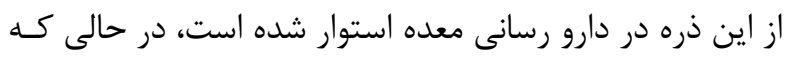

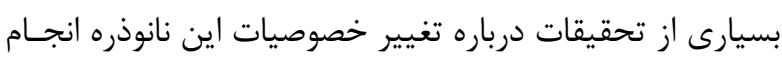

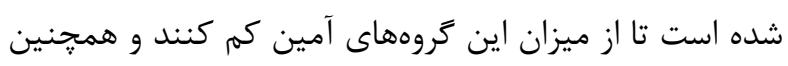




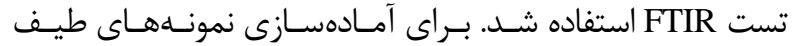
ســنجى، مقـدار كمسى از نـانوذرات كيتــوزان و كربوكسـى متيـل كيتوزان هركدام مجزا به صورت مخلـوط بــا يـودر برميـد يتاســيم سائيده و همگن شدند. يودر حاصله به صورت قرص نازكى در آمده

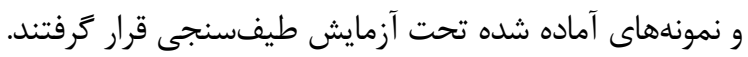
ميكروسكوٍ الكترونى عبورى TEM: براى شكل شناسى نانوذرات

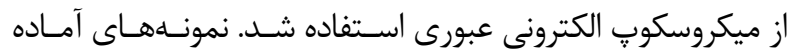

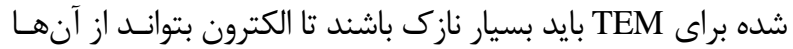

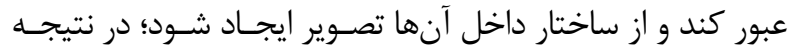
آماده سازى نمونه نيازمند دقت بالايى است. نمونههاى كيتـوزان و و

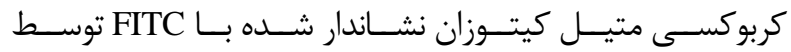

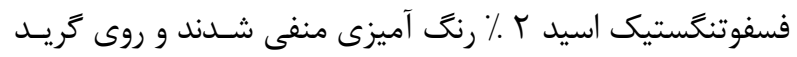

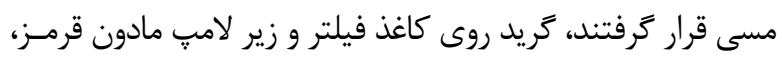

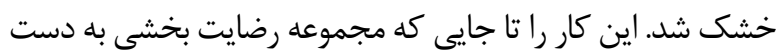

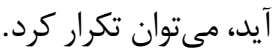
هايدارى نانوذرات در شرايط متفاوت پإيدارى نانوذرات در pH هاى مختلــف: در ايسن فراينـد بـراى

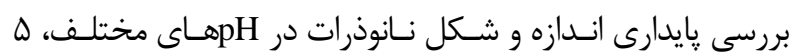

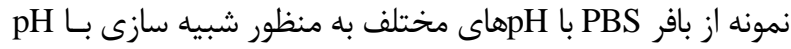
دستخاه گوارش تهيه شد. ذرات به عنوان مسير معده تحت تمـاس

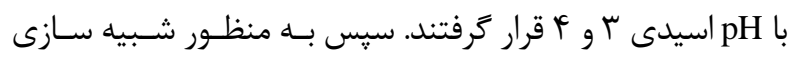

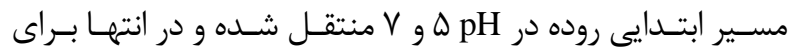

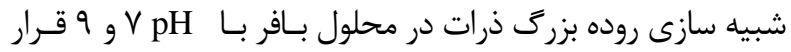

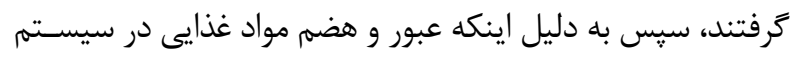

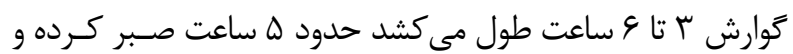
بعد براى بررسى تغيير اندازه نانوذرات تست DLS گرفته مىشود. بإيدارى نانونرات در غلظت هاى مختلف نمكس: براى بررسىى ״ايدارى نانوذرات كيتوزان و كربوكسى متيل كيتوزان نشاندار شده در غلظتهاى مختلف نمك، از نمك سديم كلريــد اسـتفاده شـد.

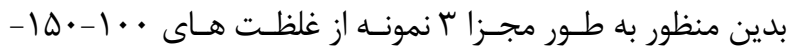
• له ميلى مولار نمك تهيه كرديد. بعد از ه ساعت تغييرات انسدازه نانوذرات توسط دستخاه DLS آناليز شد. بإيدارى نانوذرات كيتوزان در غلظت هاى مختلف از آنــزيم كوارشسى: براى انجام اين آزمايش از آنزيم ترييسين اسـتفاده شـد.

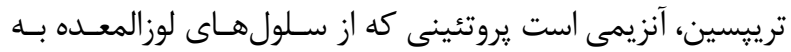

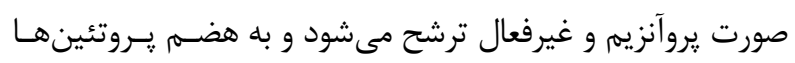

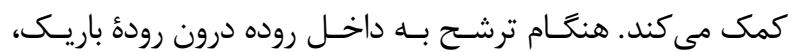

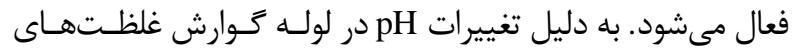

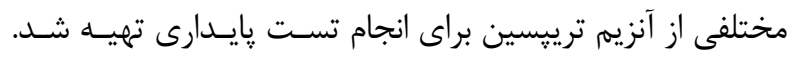

يروتونه شده و تبديل به (

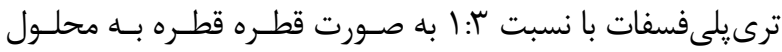

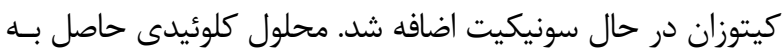

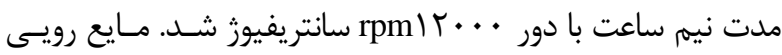

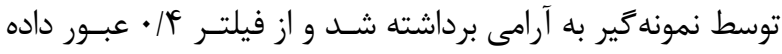

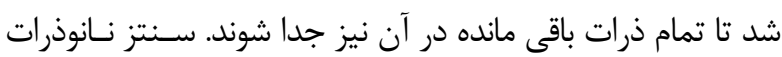
كربوكسى متيل كيتوزان نيز طبق همين روش انجام شد.

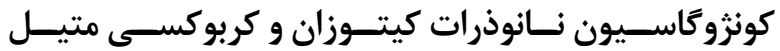
كيتوزان با فلوئورسين ايزوتيوسيانات (FITC)

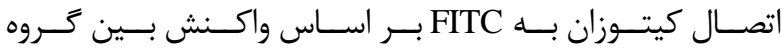
ايزوتيوسيانات FITC و گروه آمين اوليه كيتوزان ايجـاد مسىشـود. بدين منظور FITC حين همزدن در استيرر در تاريكى بـه متـانول اضافه شد. در مرحله بعد به طور مجزا كيتوزان خالص و كربوكسى متيل كيتوزان در استيك اسيد حل شد و به صـورت قطـره قطـره

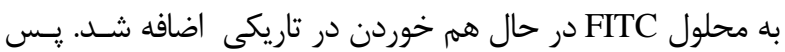

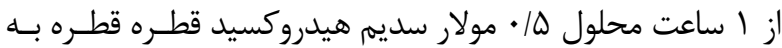
محلول اضافه شد تا جايى كه رسوب تشكيل شد. محلول به مـدت

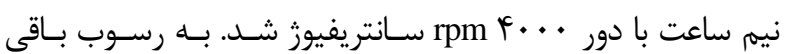
مانده در ته ظرف مقدار \ ميلـى ليتـر اسـتيك اسـيد ه/ • مـولار

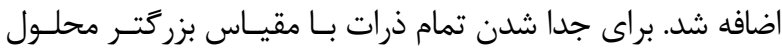

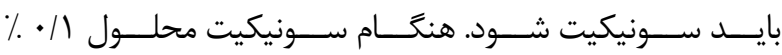
ترى يلىفسفات قطره قطره به محلول كيتوزان-FITC اضـافه شـد.

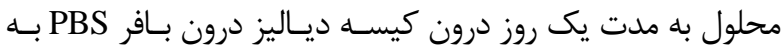

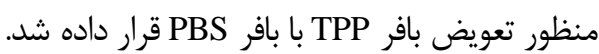

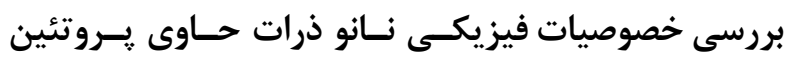

FITC براى بررسى خواص فيزيكى نانوذرات كيتوزان و كربوكسى متيـل كيتوزان نشاندار شده با FITC از جمله اندازه، يتانسيل سطح ذرهـ،

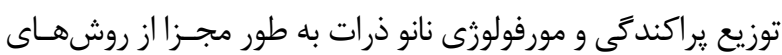
زير استفاده شد: يراكندگى نور ديناميكى (DLS): براى تعيين اندازه، ميزان توزيــع

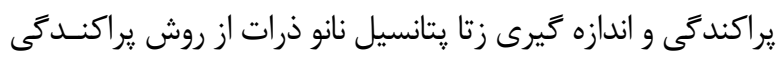
نورى ديناميك (DLS) استفاده شد. بدين ترتيب كه محلـول نـانو ذرات كيتوزان و كربوكسى متيـل كيتـوزان حساوى FITC بعـد از

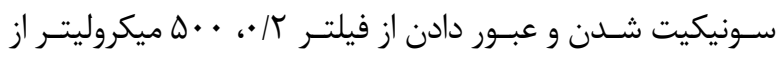
نمونه، داخل سل دستخاه قرار گرفت و يتانسيل سطح و انـدازه ذره

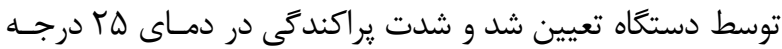

سانتى گراد، با ضريب شكست 1.335 اندازه كيرى شد.

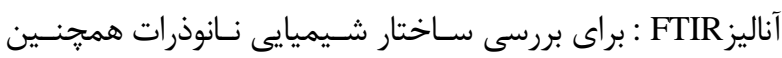
تاييد توليد كربوكسى متيل كيتوزان و اتصال نانوذرات بــ FITC از 
ارتعاش گروههاى ر ا نشان مىدهد كه به دليل ساختارهاى باز بيشتر در نتيجه كراس لينك كيتوزان با

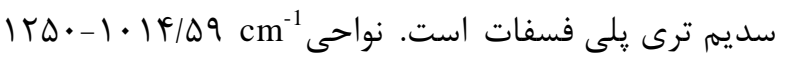

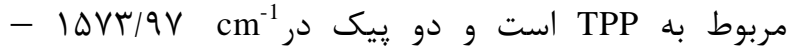

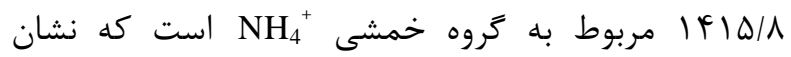
دهنده ميان كنش بين گروههاى فسفات و كروهوهاى

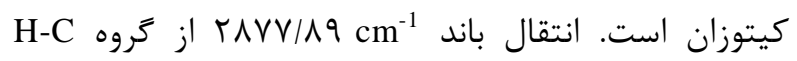

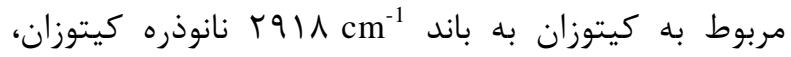
نشان دهنده تبديل كيتوزان به نانو ذره است.

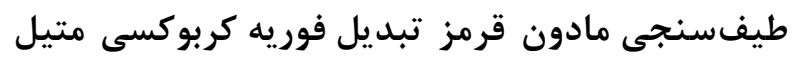

كيتوزان(FTIR) براى مشخص كردن ميزان و محل جانشينى گروههاى كربوكسيل روى كيتوزان از تكنيك FTIR استفاده شد.

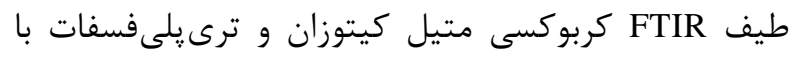
نسبت 1:1 در شكل ץ آورده شده است. در مقايسه با طيفهاى كيتوزان، در طيفهاى كربوكسى متيل كيتوزان

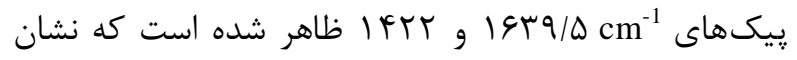
مى دهد كربوكسى متيله شدن بر روى هر دو كروه آمين و

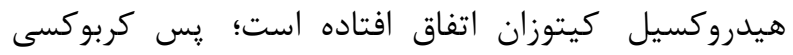

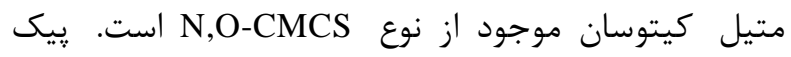

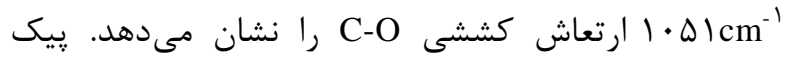
يهنتر وكششى N-H و

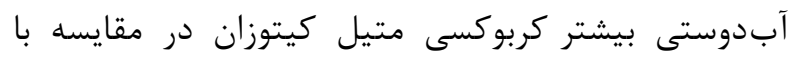
كيتوزان را نشان مى دهد.
آنـزيم ترييسـين در معـده بـا كمتـرين غلظـت و در ابتــداى روده

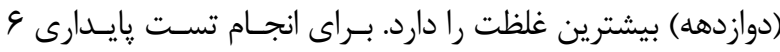

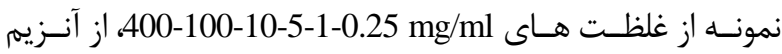

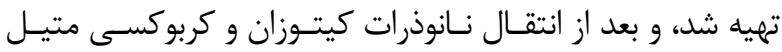

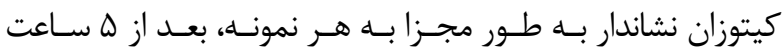

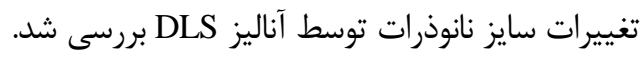

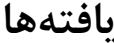

نمودار بررسى اندازه نانوذرات كيتوزان نتايج به دست آمده از بررسى اندازه نانوذرات به وسيله

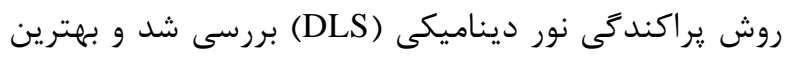
نتيجه در شكل ا آورده شده است. همان طور كه از ندان نتايج مشخص است، درصد بالايى از ذرات ايجاد شده در محدوده

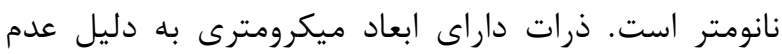

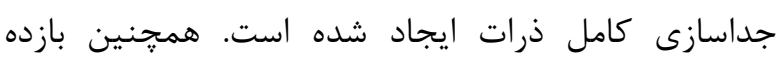
فرايند توليد نانوذرات در حدود ه9 ٪ درصد است. نانوذرات إنات

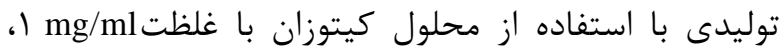

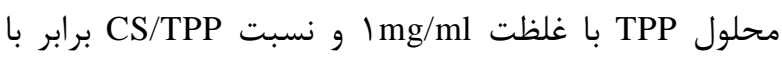
1:ا به دست آمد. متوسط اندازه به دست آمده نيز برابر با باليك

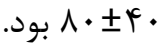

طيف سنجى مادون قرمز تبديل نانوذره كيتوزان (FTIR)

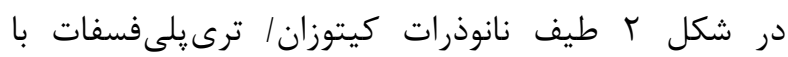
نسبت 1:1 نشان داده شده است. باند

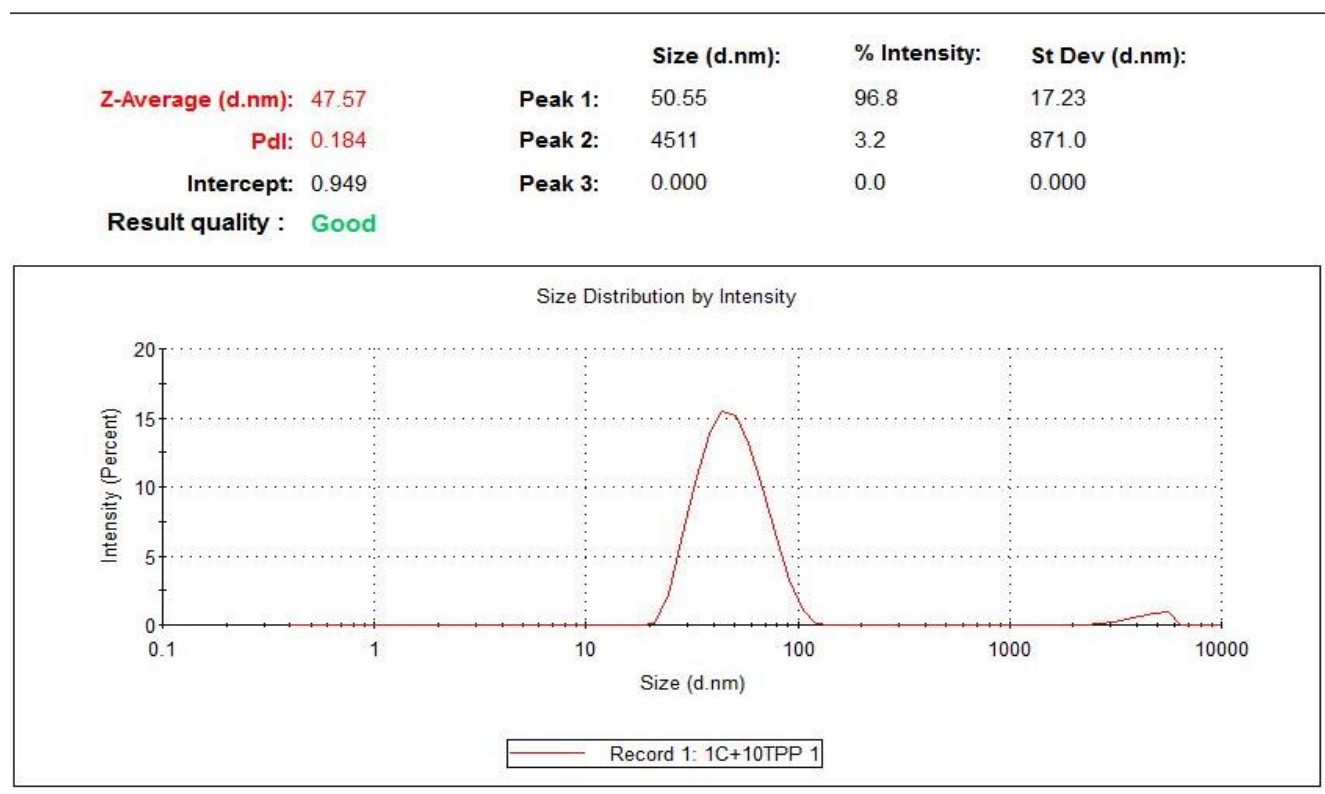

شكل ا. نتايج حاصله از بررسى اندازه نانوذرات كيتوزان با نسبت ا: IPP 


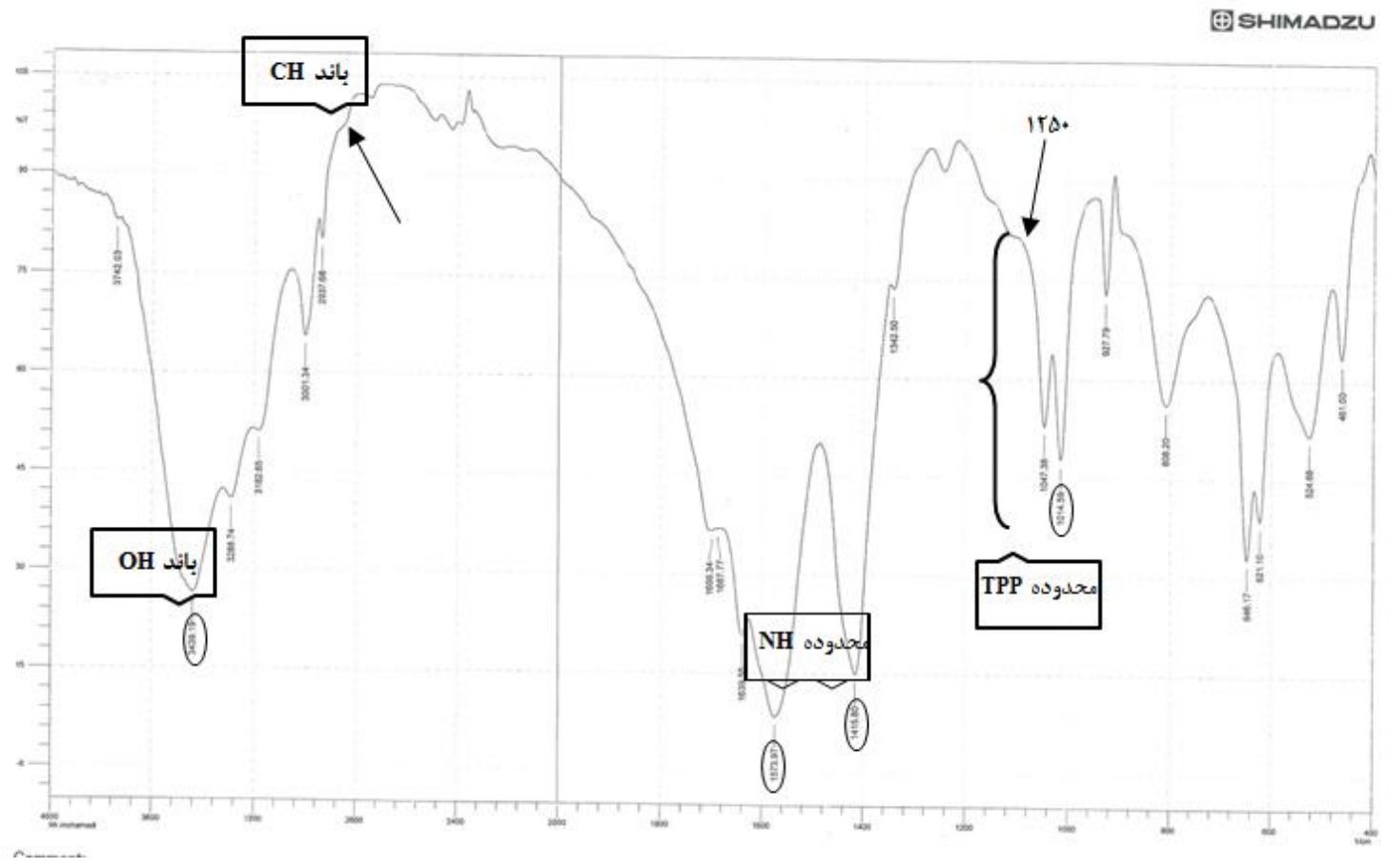

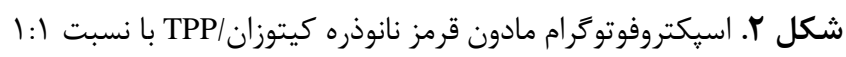

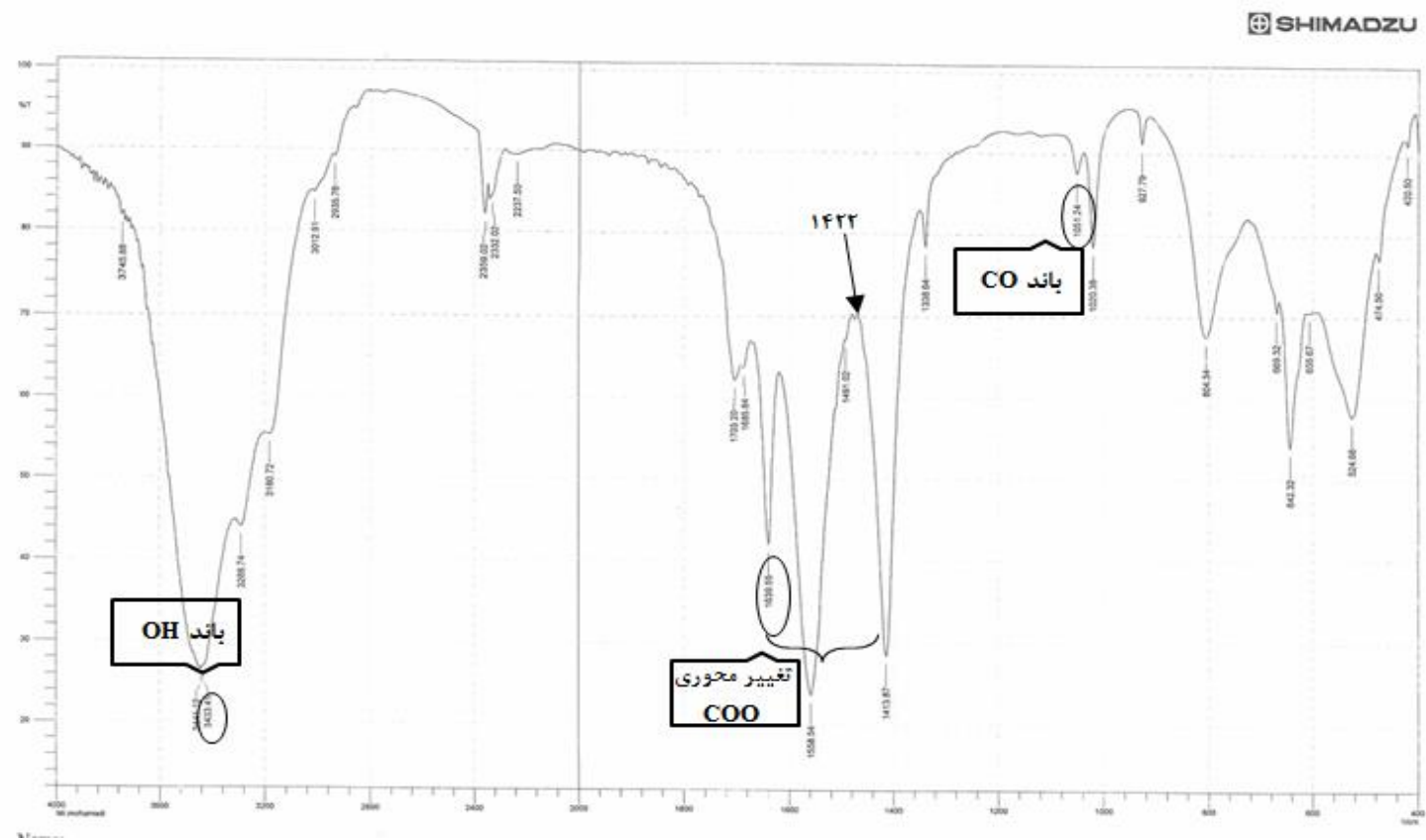

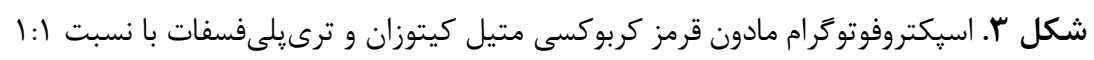

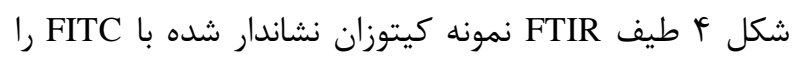

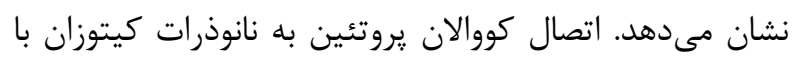
نمونه كنترل تاييد شد. اين اتصال با ايجاد بِيوند هاى كووالان بان بين آمين هاى اوليه و كروه كربوكسيل فعال شده ايجاد

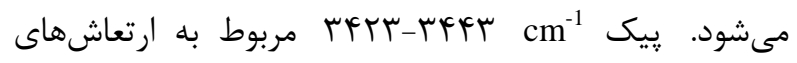

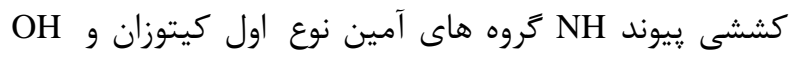
كروههاى هيدروكسيل و كربوكسيل كيتوزان و FITC است.

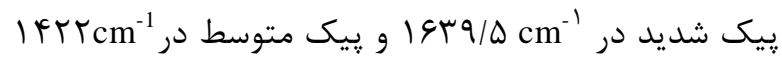
به ترتيب به تغيير شكل محورى متقارن يا نامتقارن SOO است كه وجود كروه هاى كربوكسى متيل را در كيتوزان

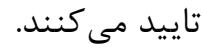
آزمون طيفسنجى مادون قرمز تبديل فوريه نانوذرات كيتوزان نشاندار شده با (FTIR) FITC) 


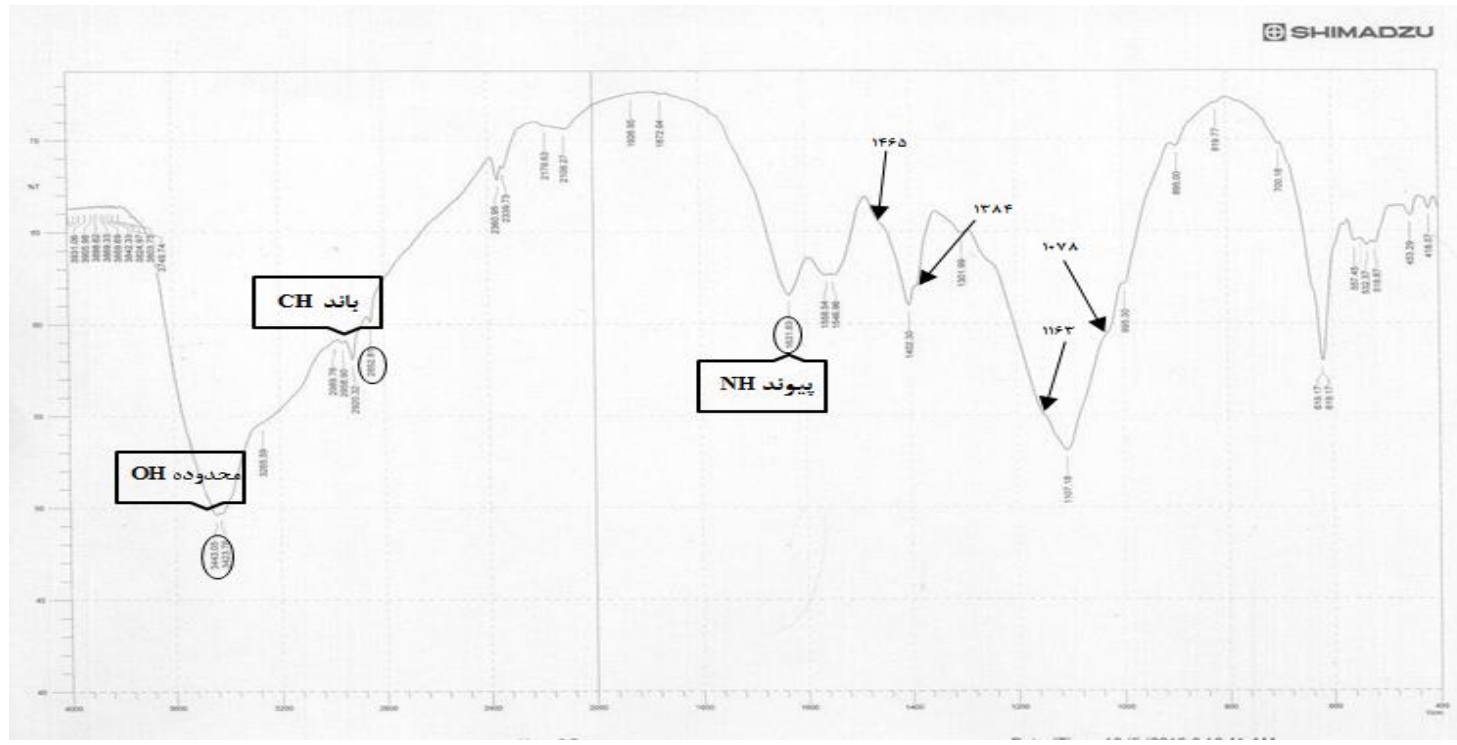

شكل F. اسيكتروفوتوكرام مادون قرمز نانوذره كيتوزان نشاندار شده با FITC

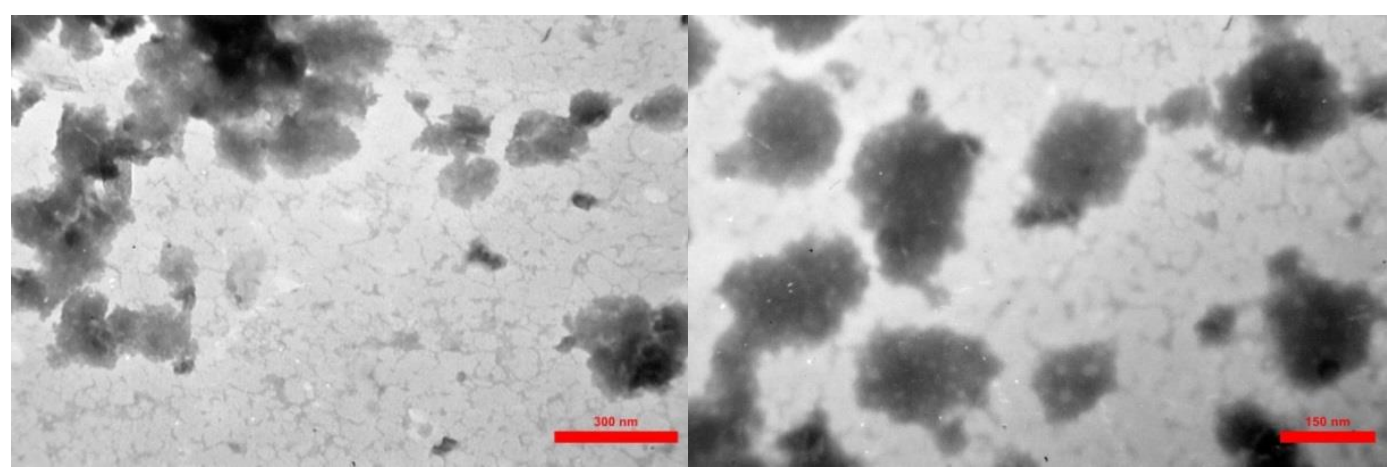

(1)

(r)

شكل ه. تصوير ميكروسكوٍ عبورى از نانوذرات. ( ) تصوير ميكروسكوٍ عبورى از نانوذره كيتوزان نشاندار شده با FITC؛ (†) تصوير

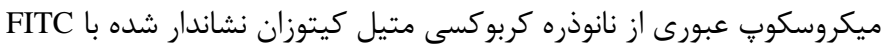

بررسى يايدارى نانوذرات كيتوزان و كربوكسى متيل

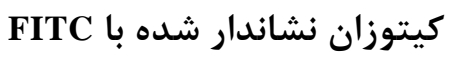

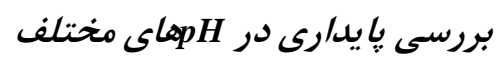

طبق نتايج به دست آمده مشخص شد كه نانوذرات كيدات كيتوزان در محيط اسيدى سايز كوخكترى نسبت به محيط بازى دارند

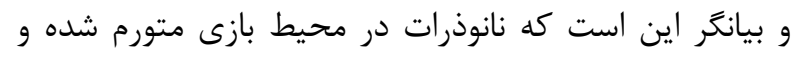
مى توانند محتويات خود را به محيط بيرون آزاد كنند، اما در

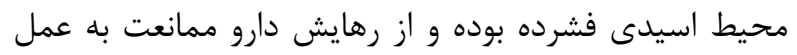

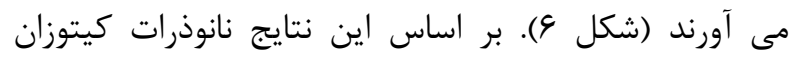

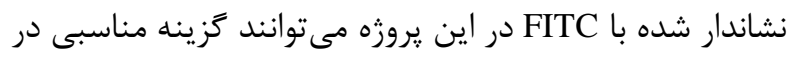
جهت انتقال دارو به روده و افزايش جذب آن بآن باشند. اما با بانيا

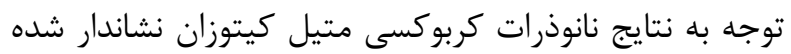

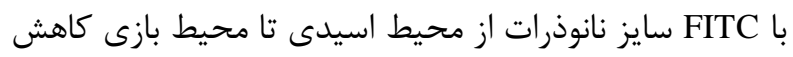

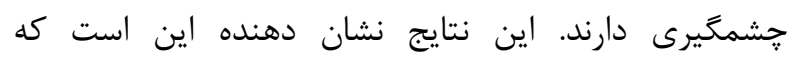
نانوذرات كربوكسى متيل كيتوزان در معده ميتواند متورم إندان

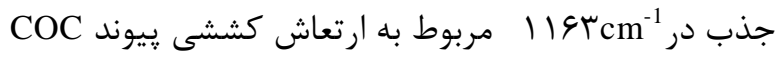

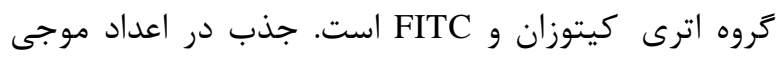

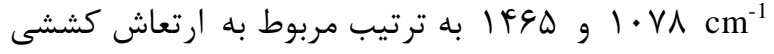

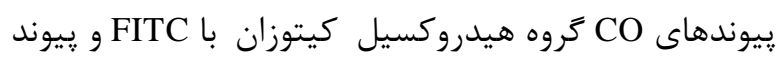
CN

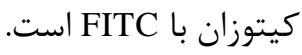

\section{ميكروسكوب الكترونى عبورى (TEM)}

به منظور تاييد اتصال نانوذرات كيتوزان و كربوكسى عبورى متيل

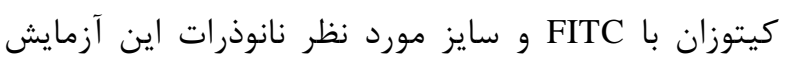
انجام شد. تصاوير حاصل در شكل ه اندازه نانوذرات در بازه

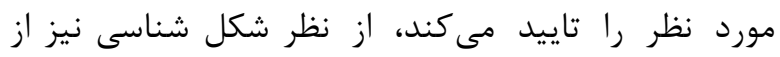
يكنواختى و كروى بودن مناسبى برخوردار هستند. 
است از محلولهاى آبى و فاقد نمك استفاده شود، و مانند هر ماده دارويى ديگرى با سيستم گوارش نسبتا خالى مورد

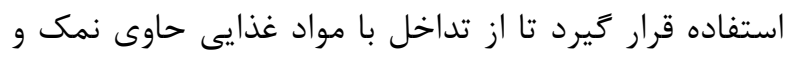
ترشح نمك هاى صفراوى تا حد زيادى جلوگيرى شود. بررسى پإيدارى در غلظت هاى مختلف آنزيم با توجه به شكل ^ غلظت آنزيم ترييسين در ابتداى روده يا

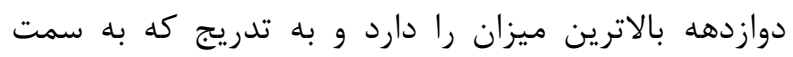
روده بزرى ييش مى رويم غلظت به شدت كاهش مى يـابد. با توجه به نتايج حاصله متوجه مىشويم كه نانوذرات كيتوزان mg/ml (FITC در غلظت باندار شده بالاى ترييسين
شوند و محتويات دارويى خود را آزاد كنند. اما براى دارورسانى در روده گزينه مناسبى محسوب نمىشوند. بررسى يا يدارى در غلظت هاى مختلف نمك

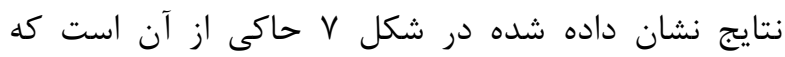
نانوذرات وضعيت ساختارى پايدارى در محيطهاى نمكى با غلظتهاى مختلف ندارند و در محدوده ميكرومتر و نانومتر

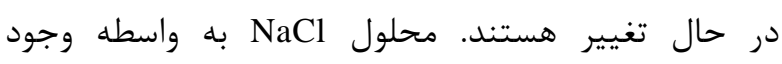
بارهاى Na مثبت و Cl منفى باعث تجمع و وريليمريزاسيون نانوذرات مى شوند و كيفيت و يايدارى آن را بانه شدت تحت

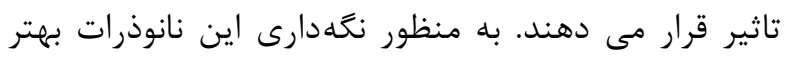

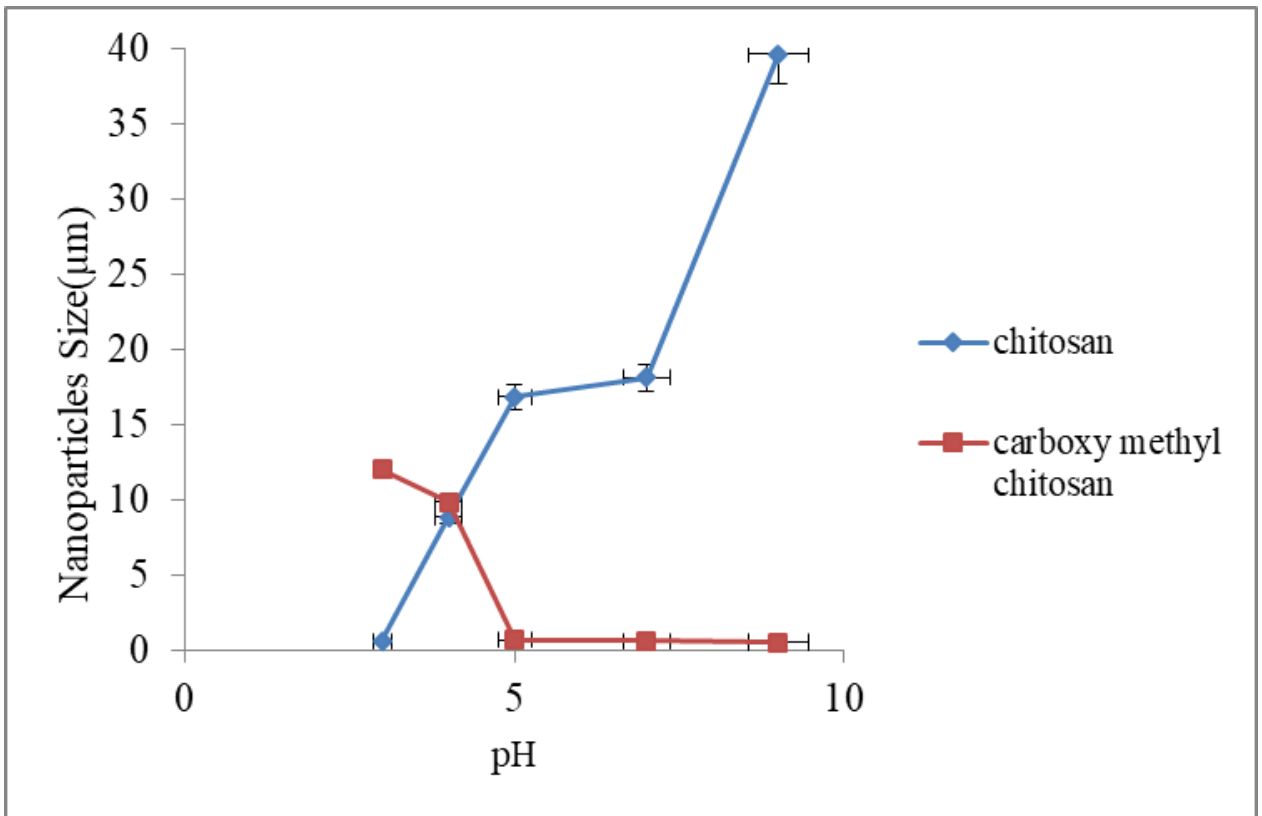

شكل 9. نمودار بررسى پايدارى نانوذرات كيتوزان و كربوكسى متيل كيتوزان نشاندار شده با FITC در pH هاى مختلف

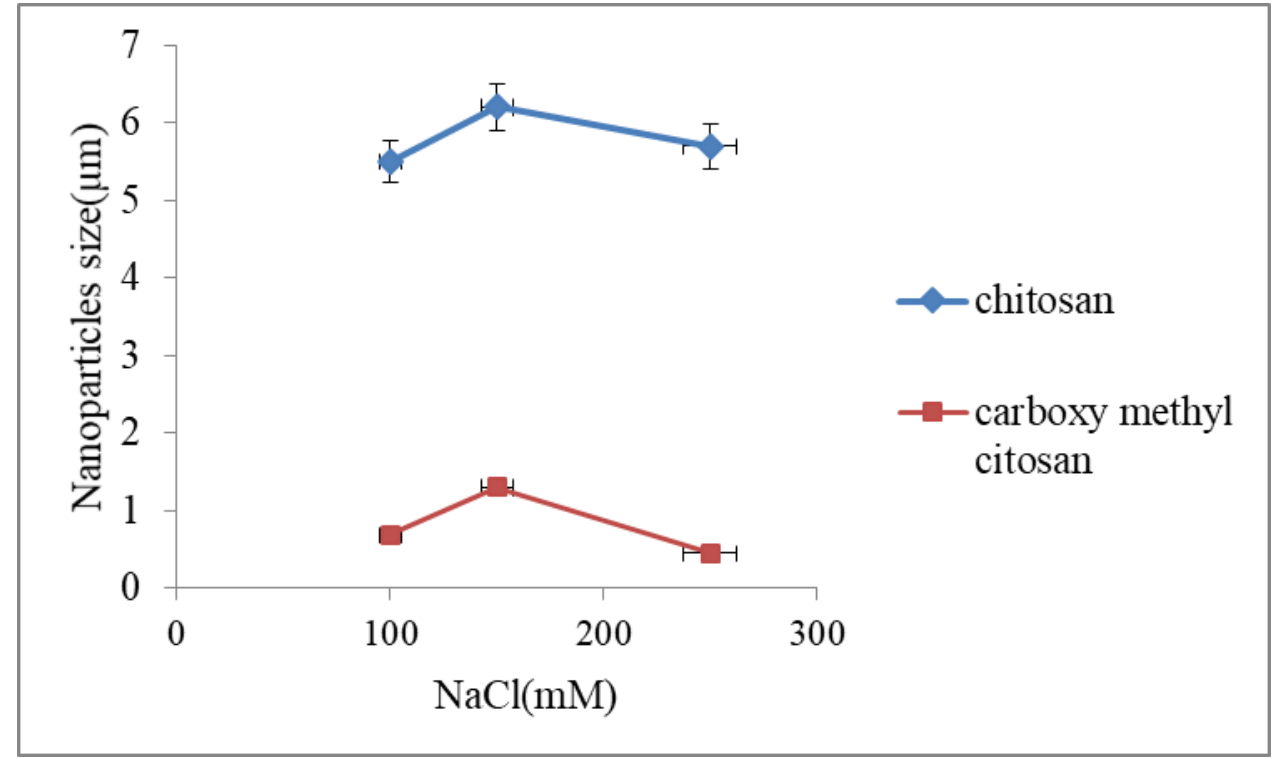

شكل V. نمودار بررسى پايدارى نانوذرات كيتوزان و كربوكسى متيل كيتوزان نشاندار شده با FITC در غلظتهاى مختلف نمك 


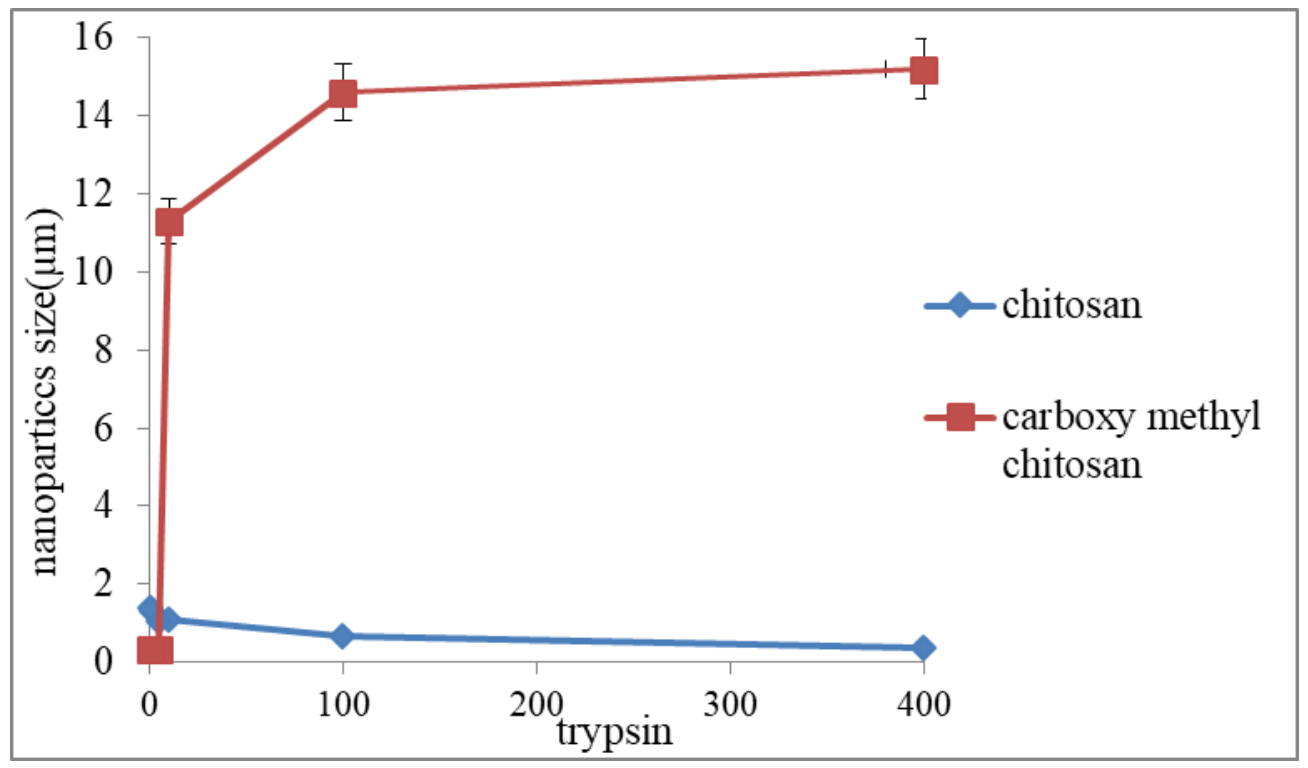

شكل ^. نمودار بررسى پايدارى نانوذرات كيتوزان و كربوكسى متيل كيتوزان نشاندار شده با FITC در غلظتهاى مختلف آنزيم

جسبندگى به مخاط و بافتهاى زنده و فعاليت ضد اسيدى خود و كاهش اثرات جانبى دارو در سيستم گوارش ميى تواند به به عنوان حامل دارويى در بيمارىهاى كولون مورد استفاده قرار كيرد (T) (1). به منظور بررسى بهتر و بهبود وضعيت ييشين از

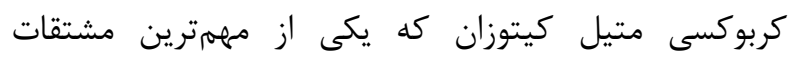
كيتوزان است هم استفاده شد. براى تهيه نانوذرات روش زل زلى شدن يونى با استفاده از مولكول ترىيلىفسفات استفاده شد اسده

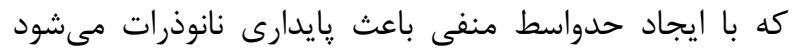

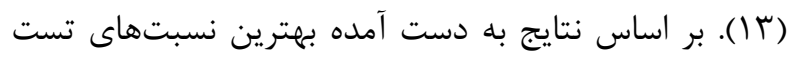
شده از TPP و نانوذره كيتوزان ا: ا، TPP و كربوكسى متيل كيتوزان نيز ا:ا است، كه در شرايط بهينه فوق الذكر داراى

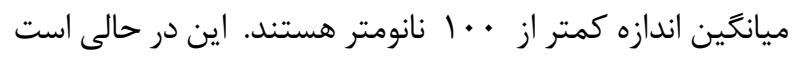

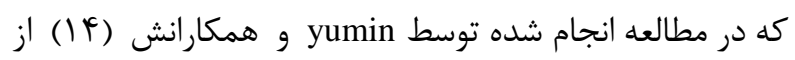
غلظت mg/ml r m- ا كيتوزان و m/ml اترى يلى فسفات براى تهيه نانوذرات توسط روش زل شدن يونى استفاده شد و

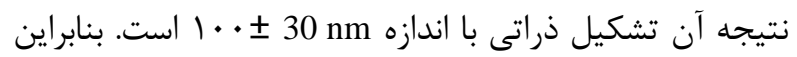
مشاهده مىشود كه نتايج حاصل از اين يروهش با نتايج انجام شده توسط yumin و همكارانش مطابقت دارد. در ززارش كار و و همكارانش كه براى اولين بار در سال r + . r به تهييه اين نانوذرات موفق شده بودند، بهترين نانوذرات نشاندار بار بار درات

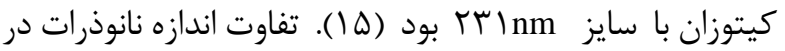
مطالعه ما با مطالعات Huang و همكارانش را اين طور مىتوان

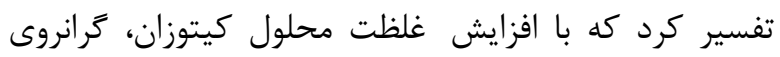
محلول افزايش يافته و مقاوت فاز مايع در برابر يراكنده شدن

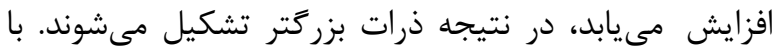

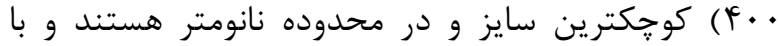
كاهش غلظت ترييسين متورم شده و در محدوده سايزى

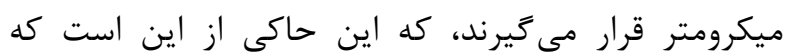
نانوذرات كيتوزان باعث تسهيل رهايش دارو در روده

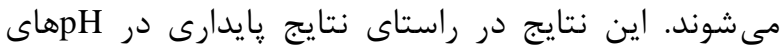
مختلف است و در هر دو موارد رفتار مشابه از نانوذرات كيتوزان مشاهده مىشود. اما نانوذرات كربوكسى متيل كيتوزان در غلظت مدرى بالاى

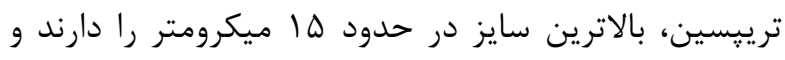

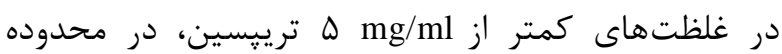
سايزى • • • • • نانومتر هستند. اين نتايج نشان مى دهد نانوذرات كربوكسى متيل كيتوزان در ابتداى روده به صورت متورم و در انتهاى روده به صورت فشرده مىباشند. يس بـ اين نانوذرات براى دارورسانى از طريق روده گزينه مناسبى محسوب نمى شوند. در عوض به منظور دارورسانى هدفمند

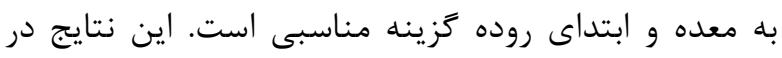
راستاى نتايج حاصل از يايدارى در ماى مختلف است.

\section{بحث}

براى دستيابى موفق به آزادسازى دارو در روده، دارو بايد از جذب يا محيط فيزيولوزيكى دستگاه گوارش در امان باشد و سيس به سرعت در بخش ابتدايى روده كه بهترين مكان براى

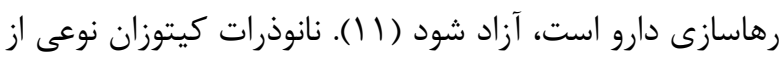
نانوذرات مورد استفاده در اين زمينه است. به دليل خاصيت 


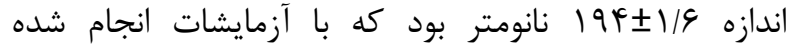
مطابقت دارد (9 (1). به منظور شبيه سازى مسير رهايش دارو

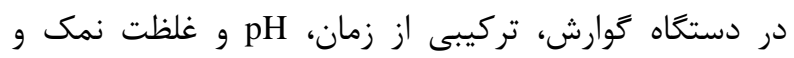
سيستم كنترل آنزيم ترييسين به منظور ساختن يك نانه نانوذره كيتوزان ويزه و كامل براى دارو رسانى به ويزه در روده مورد

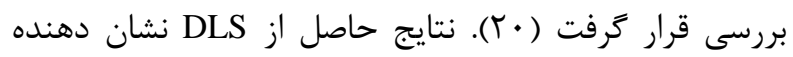

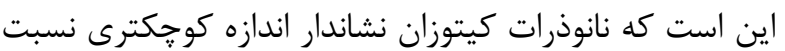
به نانو ذرات در محيط بازى دارند و از رهايش دارو در محيط اسيدى معده جلوگيرى مى كنند؛ از اين رو مىتوانند ززينه مناسبى براى انتقال دارو به روده و افزايش جذب مدي آن آن باشد. اما اندازه نانوذرات كربوكسى متيل كيتوزان نشاندار شده در محيط اسيدى تا محيط بازى كاهش يافت و نشان دهنده اين

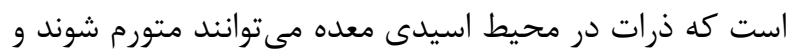

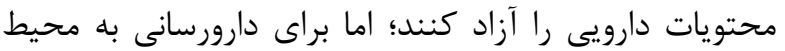
بازى روده گزينه مناسبى نيستند. در تست يايدارى با نمك NaCl زيرا بارهاى مثبت و منفى باعث : يليمريزاسيون نانوذرات مىشود. بهتر است از محلولهاى آبى فاقد نمك استفاده شود.

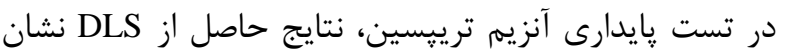

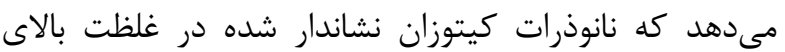
تريِيسين در محدوده نانو و داراى كوجٍكترين اندازه هستند. با كاهش غلظت ترييسين، اندازه ذرات بزرَتر شده و در محدوده ميكرو قرار مى گيرند كه باعث تورم و تسهيل در آزاد سازى

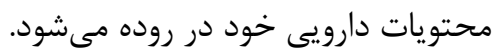

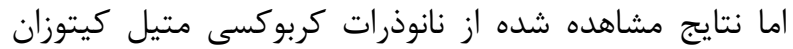
نشاندار شده نشان مى دهد كه در غلظت بالاى ترييسين اندازه ذرات در بالاترين حد خود يعنى در محدوده ميكرو است و با مبا كاهش غلظت از اندازه نانوذرات كاسته شده و در محدوده نانو قرار مى گيرد كه گزينه مناسبى براى دارورسانى به محيط اسيدى مثل معده است.
افزايش غلظت كيتوزان، مولكولهاى كيتوزان به هم نزديكتر شده و شروع به يِيجيده شدن و به هم پيوستن مى كنند كه در نتيجه يراكندگى مولكولهاى ترى يلى فسفات در دور مولكول كيتوزان مشكل و ناهمگن است كه منجر به تشكيل ذرات

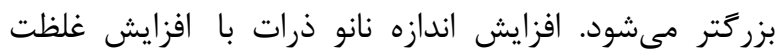

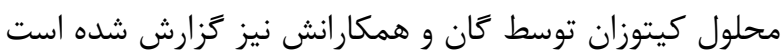

يتانسيل زتا نانوذرات كيتوزان، مثبت و حدود FV ميلى ولت بود كه نشانگر يايدارى نانو ذرات و امكان نتحهدارى طولانى مدت ذرات است. مطالعات ين و همكارانش نشان مىدهد كه نانو ذرات با بار سطحى بالاى اس ميلى ولت يايدارتر هستند و

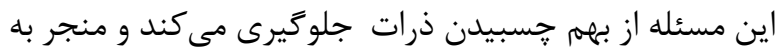
افزايش بايدارى نانوذرات مىشود (IV) به منظور شناسايى و رصد كردن نانوذرات حامل دارو در لوله كوارش در فاز in vivo از يروتئين FITC استفاده شد (1) كيتوزان و كربوكسى متيل كيتوزان هر كدام به طور مجزا با FITC قرار گرفت كه نتيجه اتصال، \9٪ بود كه اين درصد از اتصال مورد قبول است. جهت بررسى اتصالات از تست FTIR استفاده شد. طى فرايند انجام شده با تست FTIR اتصال مولكول يروتئينى FITC به نانوذرات با ايجاد گروه CN جديد ميان FITC و كيتوزان ثابت شد. براى بررسى اندازه نانوذرات تشكيل شده از تست DLS استفاده شد. نتايج حاكى از ايجاد

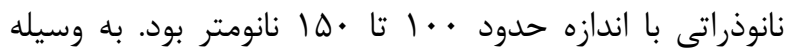
تصويرهاى به دست آمده از ميكروسكوٍ الكترونى عبورى

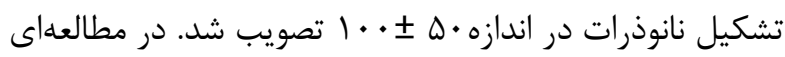

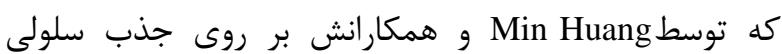
نانوذره كيتوزان نشاندار شده با FITC صورت گرفت، مشاهده شد كه كانزو Fاسيون كيتوزان-FITC با TPP توسط روش زل دنان شدن يونى با موفقيت انجام شده و نتيجه حاصل نانوذراتى بان

\section{REFERENCES}

1. Teng WL, Khor E, Tan TK, Lim LY, Tan SC. Concurrent production of chitin from shrimp shells and fungi. Carbohydr Res 2001; 332:305-16.

2. Jayakumar R, Nwe N, Tokura S, Tamura H. Sulfated chitin and chitosan as novel biomaterials. Int J Biol Macromol 2007; 40:175-81.

3. Hirano S. Chitin and chitosan as novel biotechnological materials. Polym Int 1999; 48:732-4.

4. Felt O, Buri P, Gurny R. Chitosan: a unique polysaccharide for drug delivery. Drug Dev Ind Pharm 1998; 24:979-93.

5. Grenha A, Seijo B, Remunán-Lopez C. Microencapsulated chitosan nanoparticles for lung protein delivery. Eur J Pharm Sci 2005; 25:427-37.

6. Prabaharan M. Chitosan-based nanoparticles for tumor-targeted drug delivery. Int J Biol Macromol 2015; 72:131322. 
7. Ohya Y, Shiratani M, Kobayashi H, Ouchi T. Release behavior of 5-fluorouracil from chitosan-gel nanospheres immobilizing 5-fluorouracil coated with polysaccharides and their cell specific cytotoxicity. J Macromol Sci A 1994; 31:629-42.

8. Mukhopadhyay P, Chakraborty S, Bhattacharya S, Mishra R, Kundu P. pH-sensitive chitosan/alginate core-shell nanoparticles for efficient and safe oral insulin delivery. Int J Biol Macromol 2015; 72:640-8.

9. Chen C-K, Wang Q, Jones CH, Yu Y, Zhang H, Law W-C, et al. Synthesis of pH-responsive chitosan nanocapsules for the controlled delivery of doxorubicin. Langmuir 2014; 30:4111-9.

10. McNeil SE. Nanotechnology for the biologist. J Leukoc Biol 2005; 78:585-94.

11. Win KY, Feng S-S. Effects of particle size and surface coating on cellular uptake of polymeric nanoparticles for oral delivery of anticancer drugs. Biomaterials 2005; 26:2713-22.

12. Chen S, Wu G, Zeng H. Preparation of high antimicrobial activity thiourea chitosan-Ag+ complex. J Carbpol 2005; 60:33-8.

13. Yang C-H, Lin Y-S, Huang K-S, Huang Y-C, Wang E-C, Jhong J-Y, et al. Microfluidic emulsification and sorting assisted preparation of monodisperse chitosan microparticles. Lab Chip 2009; 9:145-50.

14. Xu Y, Du Y. Effect of molecular structure of chitosan on protein delivery properties of chitosan nanoparticles. Int $\mathbf{J}$ Pharm 2003;250:215-26.

15. Yang C-H, Lin Y-S, Huang K-S, Huang Y-C, Wang E-C, Jhong JY, et al. Microfluidic emulsification and sorting assisted preparation of monodisperse chitosan microparticles. Lab Chip 2009; 9:145-50.

16. Gan Q, Wang T, Cochrane C, McCarron P. Modulation of surface charge, particle size and morphological properties of chitosan-TPP nanoparticles intended for gene delivery. Colloids Surf 2005; 44:65-73.

17. Yien L, Zin NM, Sarwar A, Katas H. Antifungal activity of chitosan nanoparticles and correlation with their physical properties. Int J Biomater 2012;2012:1-9.

18. Zambito Y, Di Colo G. Preparation and in vitro evaluation of chitosan matrices for colonic controlled drug delivery. J Pharm Pharm Sci 2003; 6:274-81.

19. Huang M, Ma Z, Khor E, Lim LY. Uptake of FITC-chitosan nanoparticles by A549 cells. Pharm Res 2002; $19: 1488-94$

20. Pridgen EM, Alexis F, Farokhzad OC. Polymeric nanoparticle drug delivery technologies for oral delivery applications. Expert Opin Drug Deliv 2015; 12:1459-73. 